\title{
PRAKTIKUM KIMIA BERBASIS KIMIA KOMPUTASI UNTUK SEKOLAH MENENGAH ATAS
}

\section{CHEMICAL PRACTICUM-BASED COMPUTATIONAL CHEMISTRY FOR HIGH SCHOOL}

\author{
Saprizal Hadisaputra $^{1^{*}}$, Lalu Rudyat Telly Savalas ${ }^{1}$, Saprini Hamdiani ${ }^{2}$ \\ ${ }^{1}$ Program Studi Pendidikan Kimia, Jurusan Pendidikan MIPA, FKIP Universitas Mataram \\ ${ }^{2}$ Progam Studi Kimia, Fakultas Matematika dan Imu Pengetahuan Alam, Universitas Mataram \\ Email: rizal@unram.ac.id
}

Received: 2 Desember 2016; Accepted: 16 Februari 2017

\begin{abstract}
Abstrak. Program pengembangan praktikum kimia berbasis kimia komputasi untuk Sekolah Menengah Atas telah dilaksanakan pada kelompok kerja guru kimia mitra (SMAN 1 Narmada dan SMAN 2 Narmada) di Kabuaten Lombok Barat, Indonesia. Kegiatan dilaksanakan dengan dengan mengadopsi langkah-langkah penelitian tindakan yang terdiri dari empat tahapan, yaitu: perencanaan, tindakan, observasi dan evaluasi, dan refleksi. Target yang telah dicapai melalui kegiatan ini adalah 1) Teridentifikasinya konsep-konsep kimia SMA yang esensial yang bisa diajarkan dengan lebih mudah bila melibatkan eksperimen berbasis kimia komputasi sebagai alternatif pengganti praktikum di laboratorium. 2) Teridentifikasinya perangkat lunak yang dapat digunakan oleh guru sebagai alternative pengganti praktikum kimia. 3) Mengukur tingkat motivasi guru sebelum dan setelah kegiatan untuk melaksanakan praktikum kimia di sekolah. 4) Adanya produk berupa buku panduan praktikum kimia SMA berbasis kimia komputasi yang dapat digunakan sebagai alternatif pengganti praktikum di laboratorium. Program ini sangat berguna untuk meningkatkan proses belajar mengajar kimia di sekolah.
\end{abstract}

Kata kuci: kimia komputasi, praktikum kimia, SMA

\begin{abstract}
Computer-based chemistry practicum development program for high school has been implemented at partner chemistry teacher group (SMAN 1 Narmada and SMAN 2 Narmada) in West Lombok District, Indonesia. The activities were carried out by adopting four stages of action research: planning, action, observation and evaluation, and reflection. This program has resulted in 1) the identification of essential high school chemistry concepts that can be taught more easily if they contain alternative lab-based alternatives in the laboratory. 2) the identification of software that can be used by teachers as an alternative to chemistry lab. 3) the identification of teacher motivation level before and after activities to carry out chemical lab work in school. 4) laboratory manual based on computational chemistry for high school chemistry. This program is very useful to improve the learning process of chemistry in high school.
\end{abstract}

Keywords: computational chemistry, chemistry laboratory, high school

\section{PENDAHULUAN}

Praktikum kimia adalah salah satu kegiatan inti pada pembelajaran kimia termasuk di tingkat Sekolah Menengah Atas (SMA). Namun, pelaksanaan praktikum kimia menghadapi banyak kendala di Indonesia[1]. Faktor biaya, permasalah waktu, keterbatasan alat dan bahan kimia serta bahaya yang mungkin timbul dalam pelaksanaan praktikum kimia membuat kegiatan praktikum tidak berjalan dengan baik [2]. Guru juga kurang termotivasi untuk merencanakan, mempersiapkan dan menyelenggarakan praktikum kimia dikarenakan permasalahan waktu atau beban kerja tinggi. Selain itu, tidak semua SMA memiliki laboratorium kimia dan pengolahan limbah praktikum. Banyaknya kendala di atas membuat praktikum kimia di SMA tidak berjalan optimal sehingga proses pembelajaran kimia juga tidak optimal.

Pemanfaatan teknologi seperti kimia komputasi dapat menjadi solusi bagi permasalahan tersebut. Metode kimia komputasi bersifat sangat fleksibel dan hampir semua materi praktek kimia baik level sederhana maupun dengan tingkat kesulitan tinggi dapat dimodelkan dengan baik menggunakan kimia komputasi. Tersedianya berbagai macam software kimia komputasi secara gratis harus bisa dimanfaatkan guru terutama sebagai alternatif pengganti praktikum kimia di sekolah [3]. Keuntungan lain penggunaan kimia komputasi sebagai alternatif praktek kimia di sekolah adalah biayanya murah, memiliki tingkat akurasi yang tinggi, mempersingkat waktu praktek, tidak berbahaya dan tentu dapat membantu meningkatkan 
pemahaman siswa terhadap materi kimia secara optimal $[4,5]$.

Contoh paling sederhana adalah pemodelan molekul yang pada mulanya diajarkan dengan menggunakan model tiga dimensional dengan menggunakan alat peraga berbentuk bola-bola dari bahan plastik atau kayu, kini dapat digantikan oleh visualisasi model molekul dengan perangkat lunak pada komputer [6]. Berdasarkkan laterbelakang di atas maka telah dilakukan program pelatihan pengembangan praktikum kimia berbasis kimia komputasi untuk guru-guru sekolah menengah atas. Tulisan ini akan membahas tentang materi kimia essensial yang dapat dipraktikumkan dengan kimia komputasi, perangkat lunak yang tepat untuk praktikum dan tingkat motivasi guru dalam melaksanakan praktikum kimia berbasis kimia komputasi.

\section{METODE KEGIATAN}

Pengembangan Praktikum Kimia Berbasis Kimia Komputasi untuk guru Sekolah Menegah Atas mengadopsi langkah-langkah penelitian tindakan yang terdiri dari 4 (empat) tahapan, yaitu: perencanaan, tindakan, observasi dan evaluasi, dan refleksi [7,8]. Kegiatan dipusatkan di 2 sekolah mitra yaitu SMAN 1 Narmada dan SMAN 2 Narmada di Kabupaten Lombok Barat. Guru kimia yang telah dilatih menggunakan perangkat lunak kimia komputasi dan mengembangkan panduan praktikum kimia serta diharapkan dapat mendisemilasikan pengetahuannya pada guru lain seperti melalui kegiatan MGMP.

\section{HASIL DAN PEMBAHASAN}

\section{Review perangkat lunak}

Beberapa perangkat lunak diuji sebagai alternative pengganti praktikum kimia di SMA. Review terhadap perangkat lunak tersebuut didasarkan pada beberapa kategori seperti kemudahan pemasangan atau instalasi, kemudahan penggunaan, dan kompatibilitas dengan materi kimia. Tabel 1 menunjukan keterpilihan perangkat lunak untuk aplikasi praktikum kimia di sekolah.

Tabel 1. Pilihan perangkat lunak sebagai alternatif pengganti praktikum kimia.

\begin{tabular}{|c|c|c|c|c|c|}
\hline No & Perangkat Lunak & Berbasis web & $\begin{array}{l}\text { Kemudahan } \\
\text { Instalasi }\end{array}$ & $\begin{array}{l}\text { Mudah digunakan } \\
1=\text { sangat sulit } \\
5=\text { sangat mudah }\end{array}$ & Finalis \\
\hline 1 & NWChem $^{9 *}$ & Tidak & Tidak & 2 & Tidak \\
\hline 2 & Hyperchem $^{10^{*}}$ & Tidak & $\mathrm{Ya}$ & 4 & $\mathrm{Ya}$ \\
\hline 3 & Gaussian $^{11^{*}}$ & Tidak & Ya & 2 & Tidak \\
\hline 4 & Chemlab $^{12^{*}}$ & Tidak & $\mathrm{Ya}$ & 5 & $\mathrm{Ya}$ \\
\hline 5 & WebMo ${ }^{13^{*}}$ & Ya & Tidak & 4 & Tidak \\
\hline 6 & ACD/ChemSketch ${ }^{14^{*}}$ & Tidak & Ya & 5 & Tidak \\
\hline
\end{tabular}

Setalah melalui review yang selektif maka dua perangkat lunak dipilih karena sesuai dengan kategori yang ditargetkan yaitu Hyperchem dan Chemlab. Kedua perangkat lunak ini dipilih karena kedua perangkat lunak tersebut tidak membutuhkan internet dan bisa dipasang secara lokal. Hal ini menguntungkan karena keterbatasan akses internet di SMA. Hyperchem dipilih karena bisa merepresentasikan aspek laboratorium kimia secara mikroskopis, kemudahan pemasangan, berbasis windows sehingga mudah dan sudah sangat familiar digunakan oleh para guru. Selain itu, fasilitas perhitungan Hyperchem cukup lengkap. Perhitungannya bisa dilakukan pada berbagai tingkat perhitungan: mekanika molekuler, semi empiris, $a b$ inito, teori fungsional kerapatan dan post-ab initio. ChemLab dipilih karena dapat mewakili aspek makroskopik untuk menjembatani praktik kimia di laboratorium. Perangkat lunak ini juga mudah digunakan, mudah dipasang dan memiliki fitur lengkap dan menampilkan aspek praktikum secara langsung mulai dari perubahan warna, perubahan fasa seperti cair, gas dan padatan dan banyak fitur lain yang sangat berguna untuk praktikum kimia di sekolah.

Beberapa perangkat lunak dieliminasi karena permasalah instalasi yang rumit, atau sulit digunakan sehingga tidak sesuai untuk proyek ini. Meski Nwchem dan Gaussian relatif mudah dipasang dan memiliki fitur lengkap, NWChem dan Gaussian cukup sulit bagi guru sehingga tidak direkomendasikan untuk digunakan. Meski mudah diinstalasi dan digunakan, ACD / ChemSketch hanya untuk visualisasi dan tidak bisa digunakan untuk menghitung sistem kimia sehingga bisa dieliminasi. 


\section{Materi Kimia Essensial}

Untuk mendapatkan materi yang essensial untuk praktikum kimia berbasis kimia komputasi telah dilakukan kajian terhadap beberapa materi penting. Hasil survei menunjukkan beberapa topik utama yang perlu diaplikasikan sebagai materi utama kerja laboratorium kimia. Guru menyarankan topik: struktur atom, sifat periodik unsur, asam dan basa, sifat fisik dan kimia dari zat, geometri molekul, energi dan termodinamika dan kimia organik untuk dilibatkan dalam praktikum kimia.

Setelah topik yang esensial diputuskan maka langkah selanjutnya adalah mengembangkan praktikum sesuai dengan perangkat lunak yang telah ada sebelumnya berdasarkan topik ini. Ditemukan bahwa topik seperti struktur atom, sifat periodik, geometri molekuler, energi dan termodinamika dan laboratorium kimia organik cocok dilakukan dengan menggunakan Hyperchem. Sebaliknya, topik seperti asam basa dan sifat fisik dan kimia zat dapat dengan mudah dilakukan dengan ChemLab.

\section{Motivasi}

Survei tersebut juga digunakan untuk mengukur tingkat motivasi guru dalam menerapkan praktikum kimia. Sebanyak 20 guru diambil sebagai sampel untuk mengetahui pelaksanaan dan motivasi kerja laboratorium kimia sebelum dan sesudah diperkenalkannya teknologi kimia komputasi untuk laboratorium kimia. Survei tersebut menunjukkan bahwa hampir 85\% guru di Lombok Barat tidak melakukan laboratorium kimia secara rutin. Sebaliknya, survei menunjukkan bahwa motivasi guru dalam melakukan laboratorium kimia dikategorikan tinggi (skor motivasi $=3,1$ interval 1-4). Kontradiksi ini mungkin karena banyak kendala seperti yang telah disebutkan sebelumnya. Pengenalan kimia komputasi sebagai laboratorium kimia alternatif tidak mengubah tingkat motivasi guru untuk menerapkan praktikum kimia dalam pembelajaran. Kabar baiknya adalah pengamatan kami menunjukkan bahwa para guru di sekolah mitra sudah mulai melakukan laboratorium kimia rutin. Kami yakin segera akan diikuti sekolah lain di Kabupaten Lombok Barat.

\section{KESIMPULAN}

Praktikum kimia berbasis kimia komputasi dapat menjadi solusi alternatif bagi raktikum kimia di SMA. Praktikum kimia berbasis kimia komputasi memiliki kelebihan seperti efisiensi waktu, tenaga, dan biaya, meminimalkan bahaya dan praktikum limbah. Secara umum guru memiliki motivasi tinggi untuk melakukan kegiatan praktikum kimia. Program pengembangan praktikum kimia berbasis kimia komputasi sangat bermanfaat bagi guru dan siswa untuk mengoptimalkan proses belajar, terutama di tingkat SMA.

\section{UCAPAN TERIMAKASIH}

Terimakasih sebesar-besarnya kepada Kementerian RISTEKDIKTI melalui Program IbM 2016 untuk bantuan dana, LPPM Universitas Mataram, Dekan FKIP Unram, Kepala Sekolah dan guru sekolah mitra serta Tim IbM 2016 yang telah bekerja keras.

\section{DAFTAR PUSTAKA}

1. Coppola, B. P. (2008). Selamat Datang di Indonesia: Learning about chemistry and chemistry education in Indonesia. J. Chem. Edu, 85(9), 1204-1209.

2. Jansen-van Vuuren, R. D., Buchanan, M. S., \& McKenzie, R. H. 2013. Connecting resources for tertiary chemical education with scientists and students in developing countries. J. Chem. Edu, 90(10), 1325-1332.

3. Fortenberry, R. C., McDonald, A. R., Shepherd, T. D., Kennedy, M., \& Sherrill, C. D. 2015. PSI4Education: Computational Chemistry Labs Using Free Software, ACS Symposium Series, Vol. 1193, pp 85-98

4. Ochterski, W, J., 2014, Using Computational Chemistry Activities to Promote Learning and Retention in a Secondary School General Chemistry Setting, J. Chem. Edu, 91 (6), 817-822

5. Sendlinger, S. C. and Metz, C. R., 2010, Computational Chemistry for Chemistry Educators, J. Comp. Sci. Edu, 1, 1, 28-32

6. Pranowo, H. D., 2011, Pengantar Kimia Komputasi, Lubuk Agung, Bandung.

7. Gall, M. D., Gall, J. P., \& Borg, W. R. Educational research: An introduction. SeventhEdition.

8. Dick, W., Carey, L., \& Carey, J. O. The Systematic Design Of Instruction. USA: AddisonWesley Educational Publisher Inc. 2001.

9. Valiev, M., Bylaska, E. J., Govind, N., Kowalski, K., Straatsma, T. P., Van Dam, H. J., ... \& De Jong, W. A. (2010). NWChem: a comprehensive and scalable open-source solution for large scale molecular simulations. Comp Phys Commun, 181(9), 1477-1489.

10. Froimowitz, M. (1993). HyperChem: a software package for computational chemistry and molecular modeling. Biotechniques, 14(6), 10101013.

11. Frisch, A. (Ed.). (2004). Gaussian 03. Gaussian.

12. Maciejowska, I., \& Bílek, M. 2009. 4.3 virtual environment on theoretical introduction and 
training of real experimentation. Interaction of real and virtual environment in early science education: tradition and challenges, 68 .

13. Schmidt, J. R., \& Polik, W. F. 2007. WebMO Pro, version 7.0; WebMO LLC: Holland, MI, USA, 2007.

14. Spessard, G. O. 1998. ACD Labs/LogP dB 3.5 and ChemSketch 3.5. J chem inform comp scis, $38(6), 1250-1253$. 